\title{
A GLOBALIZÁCIÓ A TÁRSADALOMFÖLDRAJZ VILÁGÁBAN
}

\section{GLOBALIZATION IN THE WORLD OF HUMAN GEOGRAPHY}

\author{
Mészáros Rezső \\ az MTA rendes tagja, professor emeritus \\ Szegedi Tudományegyetem Gazdaság- és Társadalomföldrajz tanszék \\ mrezso@geo.u-szeged.hu
}

\begin{abstract}
ÖSSZEFOGLALÁS
A társadalomföldrajz sokféle részterületet magába foglaló tudományág. Ennek a sokféleségnek a globalizációhoz való viszonya mindig sajátos volt. Általános egyetértés van abban, hogy a globalizáció nagy lehetőség a társadalomföldrajzi kutatás valamennyi részterülete számára. Ráadásul, a globalizáció olyan összetett és egyre átfogóbb megjelenési forma, amelynek értelmezése, bemutatása a földrajz szerepét, vitakészségét is erősíti. Ennek ellenére a társadalomföldrajzban kevés a globalizációkutatás.

A társadalomföldrajz különös érzékenységet mutat a térbeli összefüggések iránt. Nekünk, a társadalomföldrajz művelőinek, megfelelő időben észre kellett volna vennünk, hogy a világgazdaság, a kultúra, a kibertér globalizációja időben és térben gyorsan változik. De azt is érzékelni kellett volna, hogy a világgazdaság, a kulturális világgazdaság főszereplőinek térszemlélete más, mint általában a földrajz hagyományos térszemlélete. Attól tartok, hogy ez a "felzárkózás" a társadalomföldrajz részéről nem minden esetben vagy csak felszínesen történt meg. Talán ebből is következik, hogy méltánytalanul kevés a globalizációs témával foglalkozó társadalomföldrajzi szakirodalom az összes társadalomföldrajzi írás között. Feltűnő, hogy ritkán található a globalizáció világméretű összefüggéseit elemző színvonalas társadalomföldrajzi könyv vagy könyvfejezet. Inkább a globalizáció hatásait elemző publikációk jelennek meg nagyobb számban, többnyire ágazati témákban, lokális, illetve regionális megközelítésben.
\end{abstract}

\section{ABSTRACT}

Human geography is a discipline embracing lots of diverse fields. The relation of this diversity to globalization processes has always been specific. It is generally accepted that globalization is a great opportunity to all fields of researches in human geography. In addition, it has such complex and more and more comprehensive form of appearance that its interpretation and introduction from human geographical point of view strengthens the role and argumentation of geography. Even so in the human geography globalization research is rare.

Human geography shows special sensitivity to spatial connections at local, regional and global level, too. We, who work in Human Geography, should have noticed in time that globalization of world economy, culture and cyberspace is changing rapidly both in time and in space. 
But it should have also been sensed that the spatial approach of the main characters of world economy and cultural world economy is different than their traditional geographical spatial approach in general. I am afraid human geography's "catching up" has happened only on the surface or did not happened at all. This might be the reason why there is only a tiny amount of human geographical literature dealing with globalization in all human geographical literature. It is striking that a human geographical book or chapter of high standards can be only scarcely found which analyses the worldwide connection of globalization. Instead, works analysing the effects of globalization are published in large numbers dealing mainly with sector, local or regional topics.

Kulcsszavak: földrajz, társadalomföldrajz, globalizáció, a globalizáció társadalomföldrajzi értelmezése, a kibertér globalizációja

Keywords: geography, human geography, globalization, human geographical interpretation of globalization, globalization of cyberspace

\section{BEVEZETÉS}

George Benko és Ulf Strohmayer (2005) a 21. század elején felismerte, hogy a társadalomföldrajzban is létezik egy egyre bővülő kutatói közösség, amely képes dinamizálni tudományunkat, és ez új helyzetet teremtett az új iránt érdeklődő társadalomföldrajzot müvelő geográfusok számára is. De még mindig megoszlanak a vélemények abban, hogy melyek a tartós kihívások? Számos megoldás választható. Érdemes például abból a megközelítésből kiindulni, amely elvezet a társadalomföldrajz gondolatvilágának megújulásához, és újszerü földrajzi világlátást alakít ki. Ez az új gondolatvilág többségében az új, komplex rendszerek kutatási eredményeire, valamint a társadalomföldrajz „hagyományos”, valamint az interdiszciplináris és multidiszciplináris új kutatási eredményeire alapozódhat, amelyek egyre inkább kiterjednek az egész világra is, amelyek az egész világ sorsát alakítják.

Ebben a felfogásban kézenfekvő, hogy az elsők között sorakozó témakör, ami nem kerülheti el a társadalomföldrajz kiemelt figyelmét, a globalizáció. Kezdetben azonban a szerzők a globalizációról szóló írásaikban nem tértek ki a társadalomföldrajzi felületekre. Ezt tette a földrajztudomány olyan kiemelkedő személyisége, mint David Harvey és Peter Haggett is. A magyarázat voltaképpen egyszerü. A globalizációval többnyire a gazdaságföldrajz foglalkozott (ami a társadalomföldrajz részterülete). Amikor sokágúvá bővült a globalizáció, és egyre több részterületet foglalt magába a társadalomföldrajz is, jogos volt a remény, hogy (látványosan) fokozódik a társadalomföldrajzban a globalizáció iránti kutatási érdeklődés. Nem így történt. 


\section{MEGDÖBBENTŐ ADATOK}

Peter Dicken, a gazdasági földrajz világhírủ müvelője 2004-ben bírált bennünket, geográfusokat azért, hogy a földrajztudomány folyamatosan elvesztette globális tudásstátuszát a lokálissá való válásának vágya miatt. Dicken (2004) azért is panaszkodott, hogy a geográfusok a kutatásaikban konkrétan nem veszik figyelembe a globalizációt. Yehuda Dennis Wei (2006) csatlakozott ehhez a gondolathoz abban a tekintetben, miszerint a geográfusoknak időnként meg kellene védeniük a földrajz pozícióit különösen azokkal szemben, akik azt hirdetik, hogy a globalizációval a földrajznak vége van. Példaként említette Thomas Friedman (2005) világszerte ismert, híres könyvét (És mégis lapos a Föld), ami szintén megerősíti „,a földrajz vége" elméletet. Ugyancsak Dickentől (2004) származik az a megállapítás is, amely szerint a társadalomföldrajzot müvelő geográfusok közül csak nagyon kevesen (14 000 referenciából mindössze 2\%) foglalkoztak a globalizáció világméretü összefüggéseivel. Warwick E. Murray és John Overton (2015) részletezte ezt a dinamikus fejlődésnek aligha mondható folyamatot. Kiegészítésül hozzá kell azonban tenni, hogy a merítésük csak az International Bibliography of the Social Sciences (IBBS) olyan adatait vizsgálta, amelyek a legnagyobb, legelfogadottabb akadémiai közleményekben jelentek meg, és nagy jelentőségüek. Vagyis az adatok némileg megtévesztőek, mert nyilvánvaló, hogy az adott időszakban másutt is jelentek meg publikációk, mégis, az IBBS-adatok kifejezik a tényleges folyamatot. A globalizáció elöször a tanulmányok címében vagy kulcsszóként 1983-ban jelent meg. 1990-ben is csak kevés cikk tartalmazta a 'globalizáció' kifejezést, de 2003-ban már 2909 tanulmány foglalkozott a globalizációval, három évvel később, 2006-ban már 3614. Ez az időszak volt a geográfia globalizáció iránti érdeklödésének gyors, felfelé ívelő időszaka. Viszont 2012-ben is csak mindössze 1621 globalizációval foglalkozó munka jelent meg. Jól érzékelhető tehát, hogy a szerzők általában geográfusokat említenek, nem differenciálnak szakterület szerint. Különös dolog ez, mert miközben a társadalomföldrajz nem nagyon jeleskedett a globalizáció kutatásában, vannak közgazdászok, akik társadalomföldrajzi témát művelnek. Bernek Ágnes idézte a Nobel-díjas Paul Krugmant: „Bár egész életemben a nemzetközi közgazdaságtan kutatásával foglalkoztam, de csak közel egy éve ismertem fel, hogy valójában mindvégig a gazdaságföldrajzról írtam és gondolkodtam anélkül, hogy ennek tudatában lettem volna" (Krugman, 1991).

\section{A TÁRSADALOMFÖLDRAJZ ÉS A GLOBALIZÁCIÓ}

A társadalomföldrajz sajátos vagy inkább különös helyzetben van a globalizációval kapcsolatban. Kétségtelen, hogy megfigyelhető egy fejlödő összefüggésrendszer, de vele együtt kitủnik a számtalan bizonytalanság is. Egyrészt a társadalom- 
földrajz részterületei eltérő intenzitással és különböző időszakban kapcsolódtak be a globalizáció folyamatába, annak értelmezésébe. Ez tulajdonképpen természetesnek mondható. Másrészt a társadalomföldrajz müvelöi között bőven vannak, akiknek hiányos a felkészültségük a globalizáció elméletében, és ez a bizonytalan elméleti háttér esetenként nem előnyös. Ezért találkozunk elég gyakran olyan megfogalmazásokkal, hogy „a globalizáció hatása” vagy „,a globalizáció következménye" - minden részletesebb kifejtés nélkül.

A nemzetközi szakirodalomban figyelemre méltó egyéb sajátosságok is észrevehetők a globalizációs témakörrel kapcsolatban. Feltűnő, hogy nagyon kevés a globalizáció világméretü összefüggéseit elemző színvonalas társadalomföldrajzi könyv, könyvfejezet. Korábban kevés olyan társadalomföldrajzi monográfia jelent meg, amely érdemben foglalkozott volna a globalizációval. Az elmúlt két évtizedben növekedett ugyan az új társadalomföldrajzi monográfiák száma, amelyek mindegyike tartalmaz globalizációval foglalkozó fejezetet, vagy az egyes fejezeteken belül kitértek a globalizációval kapcsolatos összefüggésekre, de ennek ellenére a jellemző tendencia az, hogy a társadalomföldrajz inkább a globalizáció következményeit, hatásait vizsgálja, többnyire lokális, illetve különböző méretủ regionális szinteken, többnyire ágazati megközelítésekben. Úgy tünik, hogy ezek a méretek, szintek adnak jobb lehetőséget a részterületeknek. A kutatók azt gondolják, hogy mivel így a globalizációkutatás sokkal konkrétabb, egyben értékesebb is. Érdekes tapasztalat, hogy ha kifejezetten nem a globalizációt elemzi a szerző, akkor is valamilyen összefüggésben megemlítette azt.

A magyar társadalomföldrajzi geográfia a nemzetközi tendenciától kissé eltérő képet mutat. Elsősorban abban a tekintetben, hogy lényegesen kevesebb a globalizáció világméretü összefüggéseit társadalomföldrajzi szempontból komplex módon elemzö, feltáró, értékelő könyv vagy nagyobb tanulmány. Feltételezhetően ez azért alakult így, mert a társadalomföldrajzot müvelő geográfusok egyrészt egyetértenek a magyar közgazdaságtudomány kiválóságainak a globalizációval kapcsolatos nézeteivel. Másrészt különösebben nem kifogásolják a nemzetközi társadalomföldrajzi kutatásoknak a globalizációval kapcsolatos eredményeit sem. A magyar geográfusok a globalizációkutatás más vonatkozásaiban nem különböznek lényegesen a nemzetközi trendtöl.

Úgy tünik tehát, hogy a társadalomföldrajzot mindig is uralták a lokális és a regionális (illetve esetenként és különösen újabban a nagytérségi) témakörök. Kétségtelen, hogy a társadalomföldrajz kutatói sok irányból és sok tudományterületről kapnak (kaptak) információkat a globalizációról, de számos nézet van jelen a globalizációval kapcsolatban a szakterületen belül is. Ezért talán könnyü belátni, hogy a társadalomföldrajz számára a globalizáció olyan összetett és egyre átfogóbb megjelenési forma, amelynek feltárása és értelmezése a földrajz szerepét, tudományos rangját, érdemi naprakész vitakészségét is erősíti. A helyzet azonban nem biztos, hogy ilyen egyszerü. A globalizáció fogalmához többnyire 
minden tudományterület hozzátette a maga sajátosságait, így a társadalomföldrajz is, melynek sajátja, hogy mindig különös érzékenységet mutatott a térbeli öszszefüggések iránt. De legalább három körülményre nem minden esetben figyeltek kellően a társadalomföldrajz művelői:

- a világ gyors és egyenetlen fejlődésére,

- a világban történő nagy összefüggések viszonylag gyors változásaira,

- és arra, hogy a világgazdaság fószereplöinek térszemlélete eltérő gondolkodási pályán müködik.

A földrajztudományban fordulatnak szokás nevezni azokat a nagy változásokat, amelyek lényeges hatást fejtenek ki a teljes tudományterületre. Volt térbeli fordulat, kulturális fordulat, amelyek mindegyike jelentősen hatott a geográfia megközelítéseire, módszertanára és filozófiájára, de voltak kisebb, az egyes részterületeket érintő fordulatok is. A múlt század 70-es éveitől kezdődően minden bizonnyal ilyen hatással volt az egész földrajztudományra a globalizáció - még ha a kutatási érdeklődésben ez nem is jelent meg. Ennek ellenére valamiféle globalizációs fordulatot vagy legalább kiemelést lehetett volna kinyilvánítani, a kétségek ellenére, de azért számos tény birtokában. Például Ian Hamilton (1999) utalt arra, hogy a globalizáció tudományos elemzése két irányból indult meg az 1960-as és az 1970-es években. Az egyik irány a világgazdaság rendszerként történő felfogása (Wallerstein, 1974). A másik irányt a Nemzetközi Földrajzi Unió (IGU) Ipari Rendszerek Bizottsága képviselte. A Bizottság 1976-ban azt hangsúlyozta, hogy figyelni kell arra a térbeli folyamatra, amely a globális Kelet-Nyugat-, ÉszakDél- és a Kelet-Nyugat-Dél-kölcsönhatások kialakulásán belül zajlik, beleértve a multi- és transznacionális vállalatok növekedését és a nemzetközi integrációk termelési rendszereinek hatásait is. De a globalizáció szélesebb körü és mélyebb társadalomföldrajzi vizsgálata azonban csak később, a 20. század végén és a 21. században jelent meg, de ekkor is csak a fentebb körvonalazott megszorításokkal vagy inkább korlátozottságokkal.

A globalizáció társadalomföldrajzi értelmezései lényegében a globalizáció többnyire elfogadott meghatározásából indulnak ki, és ebben keresnek földrajzi (társadalomföldrajzi) jellemzőket. Az egyik meghatározó gazdaságföldrajzi értelmezést Peter Dicken (2015) adta. Dicken a globális gazdaság fejlődését vizsgálta földrajzi szempontból. Úgy tapasztalta, hogy a globális gazdaságban a gazdasági kapcsolatok minősége alakul át a földrajzi térben és nem egyedül a gazdasági kapcsolatok számának növekedése lesz a meghatározó tényező. Mindez azonban nem egyetlen folyamatot jelent, hanem számos folyamat együttesét. Ezért a globalizáció lényegében többközpontú, több léptékben múködő, sok formában megjelenő, többidejű folyamatok sorozata. A globalizációs folyamatok számos földrajzi formában is megjelennek, és sok térbeli folyamatra fejtik ki hatásukat a lokalizációban, a nemzetköziesedésben, a regionalizációban és magában a globalizációban. Dicken érde- 
me az is, hogy számos, addig többnyire a közgazdaságtanban használt fogalmat tett a gazdaságföldrajz (társadalomföldrajz) számára jól érthetővé.

Egy másik mértékadó álláspontot Paul Knox és Sallie Marston (2014) képvisel. Fölfogásuk szerint a mai globalizáció a világ különböző részeinek növekvő összefüggése az azonos gazdasági, környezeti, politikai és kulturális változások folyamatain keresztül. A jelenkori globalizációnak négy alapvető sajátossága van, amely megkölönbözteti a korábban lezajlott globalizációs folyamatoktól:

- a jelenlegi globalizációs folyamatok sokkal gyorsabban funkcionálnak,

- a mostani globalizáció szélesebb skálán müködik, és a legtávolabbi helyekre is eljut,

- a globális kapcsolatok térben lényegesen szélesebb körben és

- több dimenzióban érzékelhetők, mint korábban.

A globális tényezők széles körének egymásra kifejtett előnyös és előnytelen hatásai, a helyek és a régiók kapcsolatainak sok új formáját és szintjét hozták és hozzák létre.

Kétségtelen azonban, hogy az elmúlt harmincöt-negyven évben a telekommunikációs technológiák, a nagyvállalati stratégiák, az intézményi keretrendszerek kombinációja rendkívül dinamikus, új földrajzi keretet hozott létre. A jelenlegi globalizáció gazdasági alapja, a megszámlálhatatlan árucikk, a hálózattól függ, amely a globális teret kitölti. Az új típusú mobilitás valójában legalább négyféleképpen növeli a helyek (a földrajz egyik alapkategóriája) jelentőségét.

- minél univerzálisabb az anyagi kultúra és az életstílus diffúziója, annál értékesebbé válnak a regionális és az etnikai identitások,

- minél gyorsabb információs útvonal viszi el az embereket a kibertérbe, annál jobban érzik egy olyan szubjektív terület szükségét, amelyet sajátjuknak tekinthetnek,

- minél távolabbra érnek a transznacionális vállalatok, annál könnyebben tudnak válaszolni az adott helyeken felmerülő munkapiaci és fogyasztópiaci kérdésekre,

- minél nagyobb a transznacionális vállalatok, szervezetek integrációja, annál érzékenyebbé válnak az emberek faji, vallási és etnikai különbségeire.

Knox és Marston (2014) fenti megközelítései nagyon érdekes megállapítások. Ezek a tételek társadalomföldrajzi szempontból fontosak, mert közvetlen társadalomföldrajzi tartalmakat foglalnak magukban, szinte valamennyi részterület talál aktuális kutatási témát (a multi- és a transznacionális vállalatok térbeli és belső társadalomföldrajzi kérdései, az új típusú városnövekedés, globális városok, pénzügyi központok globális térbeli rendszere stb.).

Egy másik felfogásnak egészen eltérő a kiindulópontja. Warwick E. Murray és John Overton (2015) a globalizációfogalom társadalomföldrajzi tartalmát abban 
látták, hogy míg sokak szerint a globalizáció szinte homogenizálja a világot, addig a geográfia képes arra, hogy empirikus adatokkal és elméleti konstrukciókkal megcáfolja ezt az állítást.

Egyébként voltak és vannak, akik a globalizáció előretörését, megerősödését és átfogó jellegét úgy minősítették, hogy ez az a körülmény, amely egyfajta dinamizmust ad a társadalomföldrajznak. Ennek a szemléletnek a hívei elérkezettnek látták az időt arra, hogy jó koncepciókkal, jobb elemzésekkel folyamatosan modellezzék, teszteljék, mérjék és nyilvánosságra hozzák a globalizáció folyamatait.

Rendkívül izgalmas kérdés volt, hogy a társadalomföldrajzi elemzés a globalizáció szűk vagy egészen szélesen értelmezett tartalmára, összefüggéseire terjedjen-e ki? Természetesen jobb lehetőséget ad a szélesebb értelmezés, mert ezáltal jó alkalom nyílik a társadalmi tartalmak és a területi különbségek feltárására is. Sőt, ebben a társadalomföldrajzi megközelítésben azt is érdemes érzékelni, hogy a világ sorsának alakításában részt vevő - főként globális - föszereplők térszemlélete más, mint a miénk. Ök általában és könnyedén lépnek túl a hagyományos (földrajzi?) térkategóriákon. Ezért nagyobb fogékonyságot kellene mutatni az efféle nem szabályos és viszonylag gyorsan változó térszerveződések iránt. Ez a felfogás ad lehetőséget arra is, hogy a vizsgálat tárgya legyen a kibertér, amely egyébként már a múlt század 70-es évei óta része a globális térnek.

\section{A KIBERTÉR GLOBALIZÁCIÓJA}

Az emberiség egyik fö vágya minden korban az volt, hogy az idő legyőzze a teret. Sok próbálkozás volt, de - úgy tünik - ez csak a legutóbbi időben sikerül. A gyorsan fejlődő adatátviteli rendszerek, a globális telekommunikációs hálózatok egyre inkább megteremtették a lehetőséget arra, hogy az ember egyre gyorsabban haladhasson a térben. Ismert, hogy William Gibson (1984) science fiction író, az akkor már formálódó, gyorsan globalizálódó új térformációt találóan kibertérnek (cyberspace) nevezte el. A kibertér (virtuális tér) általában ott jelentkezik a maga térkínálatával, ahol valamilyen társadalmi igényt elégíthet ki, vagyis végső soron a kibertér tértípusai teljes mértékben társadalmi eredetủek. A kibertér hamar kedvelt lett. A fogalmat a legkülönbözőbb csoportok használták/használják a saját céljaikhoz. Az 1990-es években és az ezredforduló táján a kibertér iránt a társadalomföldrajz müvelői is kifejezetten érdeklődtek (sajnos hazánkban kevésbé). Michael Batty és Bob Barr (1994) egyenesen arról írtak, hogy új geográfia van kialakulóban, amely drámai módon változtatja meg a földrajztudományról alkotott elképzelésünket. De szinte egy időben súlyos támadás is érte a földrajzot éppen a kibertérrel összefüggésben. A „távolság haláláról”, ,a földrajz végéről” jelentek meg tanulmányok, éppen a geográfia egyik alapkategóriájának, a helynek a meghatározó szerepét csökkentendő. Ma már viszont nem vitatják a földraj- 
zi hely fontosságát. (O’Brien, 1992; Cairncross, 1995; Mészáros, 2010; Gál, 2010 és mások).

A kibertér gyors fejlődése, bővülése szorosan kapcsolódik a globalizáció terjedéséhez. A kibertér a globalizáció hordozója. Egyre több gazdasági, pénzügyi, világkereskedelmi, gazdaságirányítási tevékenység kerül „,el” a kibertérbe. Nagy jelentősége van az innováció gyors térbeli terjedésében, a gyógyászat egyes ágazataiban, a könyvtári tevékenységben, a távoktatásban, a távérzékelésben, de még a városfejlesztési kérdéseket, a globális klímaváltozást is érinti. Nélkülözhetetlen tere, szinte önálló egysége a kultúra és a média globalizációjának, a kulturális termelés és fogyasztás globális rendszerré szerveződésének (Bayer, 2002). Ma már szinte a teljes politikai kommunikáció is a kibertéren „keresztül” zajlik, de a kibertér a hordozója a világméretűvé váló lokális, regionális és globális bünözésnek és a terrorizmusnak is. Az utóbbi időben egyre erőteljesebbé vált a kibertér hadászati jelentősége. Az internet, de különösen a világháló megalkotása óta a tevékenységek szinte követhetetlen köre kerül „fel” a kibertérbe.

Sokan, még a kibertér kialakulásának kezdeti időszakában is osztották azt a véleményt, hogy a kibertér, amellett hogy nagy jelentősége van az információszállításban és feldolgozásban, igen nagy hatással van a társadalmi viszonyok és kapcsolatok alakulására is. Azóta ez a feltételezés teljes mértékben beigazolódott, ugyanis a kibertér olyan lehetőséget, térkínálatot nyújt, ahol az ember testetlenné válhat azzal, hogy olyan kölcsönhatások terébe lép és szabadul meg a testtel kapcsolatos meghatározottságoktól, mint például a nem, a bőrszín. De fontos lehet az az élmény is, amely lehetővé teszi az emberek számára, hogy helyük elhagyása nélkül mozduljanak ki tér- és időbeli helyükről, és barangoljanak. Azóta ez - különösen az okos mobiltelefonok gyors elterjedésével - világszerte, különösen a fiatal korosztálynál, súlyos társadalmi problémává vált. Peter J. Taylor már 1997ben publikálta azt a véleményét, hogy a kibertéri egyéni, társadalmi kapcsolatoknak is valójában a térbeliség ad keretet, és a leírásuk földrajzi metaforákkal történik. A virtuális világban lenni földrajzi élményt jelent, ugyanakkor, ha valaki a virtuális világban van helytől, időtől, nemtől függetlenül, akkor ez az egyén (az éntudat) egyfajta globalizációja. Már elég hosszú ideje a kibertér életünk részévé vált. Kijelenhető, hogy a kibertér nem egyszerủen egy térforma, hanem lokális, regionális és globális „világintézmény”. Áldás és átok egyaránt.

\section{KÖVETKEZTETÉSEK}

Lassan teljesül az a megállapítás, miszerint egyetértettünk abban, hogy a globalizáció (eltérő súllyal ugyan), de nagy kutatási lehetőség a társadalomföldrajz valamennyi részterülete számára. Megállapítható, hogy az utóbbi évtizedekben a társadalomföldrajz versenyképes, nagy teljesítményủ és állandó megújulásra 
képes tudományággá fejlödött, amely azonban sajnos a globalizáció világméretü kérdéseivel, az egész folyamattal csak részben tudott megfelelően, magas tudományos szinten bánni. Az utóbbi időszakban azonban egyre jobb eredmények születnek a globalizáció világméretü kutatása terén is. A publikációk azt mutatják, hogy a társadalomföldrajzban a globalizáció kutatása során a lokális, a regionális szinteken és ágazati vonatkozásokban sokkal jobb a helyzetet, előnyt élveznek ezek a kutatások. A kézenfekvő magyarázat az, hogy a társadalomföldrajz kutatási problémái, feladatai és megbízásai ezekhez a szintekhez állnak közel. Mégsem teheti meg a szakterületünk, hogy a rendszer harmadik szintjével (globális) ne foglalkozzon behatóbban és szélesebb körben. Érdekes tapasztalat vagy következmény az is, hogy a társadalomföldrajzot müvelö geográfusok nem szívesen vesznek részt a globalizációról szóló vitákban. A globalizáció elméleti kérdéseit illetően ez talán érthető, a társadalomföldrajzot kutató geográfusoknak nem feladatuk, hogy naprakészek legyenek a globalizáció aktuális elméleti kérdéseiben. A globalizáció részkérdéseiben viszont a társadalomföldrajz müvelőinek érdemes jobban keresni a tudományos kapcsolatok lehetőségét.

\section{IRODALOM}

Agnew, J. A. - Duncan, J. S. (2011): Globalization and Human Geography (in introduction). Agnew, J. A. - Duncan J. S. (eds.) (2011): Companion to Human Geography. London: Wiley-Blackwell, 3-4.

Batty, M. - Barr, B. (1994): The Electronic Frontier: Exploring and Mapping Cyberspace. Future, 26, 699-712. DOI: 10.1016/0016-3287(94)90039-6

Bayer J. (2002): Globális média, globális kultúra. Magyar Tudomány, 6, 748-764. http://www. matud.iif.hu/02jun/bayer.html

Benko, G. - Strohmayer, U. (2005): Human Geography. London: Arnold

Bernek Á. (2000): A globális világ ,új gazdaságföldrajza”. Tér és Társadalom, 4, 87-107. http:// epa.uz.ua/02200/02251/00003/pdf/EPA02251_Ter_es_tarsadalom1212.pdf

Cairncross, F. (1995): The Death of Distance. The Economist, 30 September, 336.

Dicken, P. (2004): Geographers and Globalization: (Yet) Another Missed Boat? Transactions of the Institute of British Geographers, 29, 5-29. https://www.jstor.org/stable/3804426?seq=1\#page_scan_tab_contents

Dicken, P. (2015): Global Shift. London: The Guilford Press

Gál Z. (2010): Pénzügyi piacok a globális térben. Budapest: Akadémiai Kiadó

Gibson, W. (1984): Neuromancer. London: Harper Collins

Friedman, Th. L. (2005): És mégis lapos a Föld. (ford. Bozai Á.) Budapest: HVG Kiadó Zrt.

Hamilton, I. (1999): A globalizáció és a lokális gazdasági fejlődés. (ford. Szabó P.) In: Helyek, terek, régiók. Budapest: ELTE RFT, 87-101. http://geogr.elte.hu/REF/REF_Kiadvanyok/REF_ RTT_04/REF-RTT4hu.html\#F.\%20E.\%20Ian\%20Hamilton

Knox, P. - Marston, S. (2014): Human Geography: Places and Regions in Global Context. London: Routledge

Krugman, P. (1991): Geography and Trade. Leoven Univ. Press-MIT Press 
Mészáros R. (2010): A globális kibertér. In: Mészáros R. et al.: A globális gazdaság földrajzi dimenziói. Budapest: Akadémiai Kiadó, 349-365.

Murray, E. W. - Overton, J. (2015): Geographies of Globalization. London: Routledge

O'Brien, R. (1992): Global Financial Integration: The End of Geography. New York: Council of Foreign Relations

Taylor, P. J. (1997): The Emerging Geographies of Virtual Worlds. The Geographical Review, 172-192. DOI: 10.1111/j.1931-0846.1997.tb00070.x

Wallerstein, I. (1974): The Rise and Future Demise of the World Capitalits Systems: Concepts for Comparative Analylis. Cambirgde Univ. Press

Wei, Y. D. (2006): Commentary. Environment and Planing, 38, 1395-1400. 